\title{
EDUVELOP
}

\section{Journal of English Education and Development}

Volume 1, No. 2, March 2018

ISSN 2597-713X (print)

ISSN 2597-7148 (online)

\section{Using Herringbone Technique in Teaching Reading Narrative Text at the Eighth Grade Students of SMP Negeri 9 Parepare}

\author{
Sudarmanto \\ Department of English Education, \\ Muhammadiyah University of Parepare \\ Address. Jl. Ahmad Yani KM. 6, Bukit Harapan, Soreang, South Sulawesi, Indonesia \\ Telp.+6285242811808 E-mail: Sudarmanto@umpar.ac.id
}

\begin{abstract}
This research discussed how the use herringbone technique to improve the students' ability in reading. This research used quasi experimental design that applied a pretest and post-test design. The data was analyzed by using t-test. The population of this research was the eight year students of SMP Negeri 9 Parepare in academic year 2013/2014. There were two classes, a class for experimental class and a class for control class. It utilized cluster random sampling technique. The number of each class was 30 students. The instrument used in this research was reading test use of herringbone technique in learning reading. The result of this research was a significant difference between experimental group and control group. This indicates the mean score of the post-test of experimental group was 97 while that of the control group was 92 . Moreover, the t-test value $(7,24)$ was higher than $t-$ table value (2.021). In other words, Hypothesis Alternative $\left(\mathrm{H}_{1}\right)$ was accepted and Hypothesis Null $\left(\mathrm{H}_{0}\right)$ was rejected. This means that Using Herringbone technique can improve the students' reading comprehension by using herringbone technique.
\end{abstract}

Keywords: Students, Herringbone technique, Reading ability

\section{Introduction}

In language teaching, the mastery of four language skills (listening, speaking, reading, and writing) is important. Reading

Vol. 1 No. 2 March 2018 is one of the four skills that should be mastered by the students. As a matter of fact, it is not easy for students to read the teaching materials in a foreign language. They have to face new vocabularies and Universitas Sulawesi Barat 
structures which they have not mastered yet. Reading is useful for other purposes too; any exposure to English (provided students understand it more or less) is a good thing for language students (Harmer, 1998: 68). Reading text also provides opportunities to study language: vocabulary, grammar, punctuation, and the way we construct sentences, paragraphs, and texts.

Reading in English as a foreign language is not the same as reading in the students' mother tongue, that is, South Sulawesi and Indonesian. It makes the students encounter difficulties in vocabulary, structure, pronunciation, etc. Those difficulties sometimes make them bored to read. Thus, reading should be enjoyable; otherwise, the exercise would not be worth teaching. The students think that reading English is not interesting and boring since they do not know the meaning of the words and do not find an interesting book. The students need many kinds of interesting materials so that they feel happy and motivated to learn English. Therefore, the existence of the teaching method is important.

\section{Literature}

\section{a. Herringbone Technique}

Teaching with graphic organizer is teaching technique to increase students' motivation in learning English. Graphic organizers are important and effective pedagogical tools for organizing content and ideas, and facilitating learner's comprehension of newly acquired information (McKnight, 2010: 1). The one of graphic organizers is Herringbone Technique. Herringbone Technique is graphic organizers which represent visual information and concepts in teaching learning process. McKnight

Vol. 1 No. 2 March 2018
(2010: 50) states that Herringbone Technique is used for establishing supporting details for a main idea. In addition, Herringbone Technique helps students understand the connections between supporting details to identify a main idea.

The herringbone technique is a structured outlining procedure designed to help the studens organize important information in a text. The Herringbone technique is intended for use with students in the fourth through twelve grade levels. As with several strategies within this unit, the procedure appears most appropriate for those students whose reading levels are below the difficulty levels of the adopted text (Tierney, at all( 1985:82).

The fish diagram is used to help students identify the main idea and the related supporting ideas of a lesson, text or concept. It contains six questions that help students organize the details of the text. The visual pattern of the harringbone creates a framework for students to short the information.

The herringbone technique develops comprehension of the main idea by plotting who, what, when, where, how, and why questions on a visual diagram of a fish skeleton. Using the answers to the $\mathrm{WH}$ questions, the students write the main idea across the backbone of the fish diagram.

\section{b. Procedure of Method}

The students work in pairs. The students make a group with their friend besides them, The teacher selects narrative texts. The teacher selects narrative texts which is appropriate with the reading level of the eighth grade, The teacher constructs a visual diagram of the Herringbone. The teacher Universitas Sulawesi Barat 
shows the visual diagram of Herringbone Technique to the students, The teacher tells the students to record the answers to the questions on the diagram, The students read the text to find the answers and record the answers on the diagram. The students are recording the answer of the Herringbone diagram's questions while they are reading the text, The teacher shows the students how each answer fits into a slot in a main idea sentence. After the information is recorded, the students can make the main idea of the text by using the answers of $W H$-questions, The students write a main idea, using the information from the Herringbone diagram.

After getting the main idea by using the information from Herringbone diagram, the students write the main idea on the Herringbone diagram.

\section{c. The Advantages and the Disadvantages of Herringbone Technique}

An advantage of the Herringbone Technique is to help the students for encoding the information in a manner that enhances their ability to answer essay questions. Tierney in Rafain, at. all (2013:2) Herringbone Technique also helps the students spend a few times while they are reading the text. Therefore, the students will not get bored when they read narrative text. While the disadvantage of Herringbone is when students learn material with the help of graphic representations, note-taking will be decreased. As a result, the lack of a comprehensive guide those students can refer to when revising material may affect their performance. Tierney in Rafain.

Vol. 1 No. 2 March 2018

\section{d. Procedures of Herringbone Technique}

The herringbone technique develops comprehension of the main idea by plotting who, what, when, where, how, and why questions on a visual diagram of a fish skeleton. Using the answers to the $\mathrm{WH}$ questions, the students write the main idea across the backbone of the fish diagramAs follow diagram

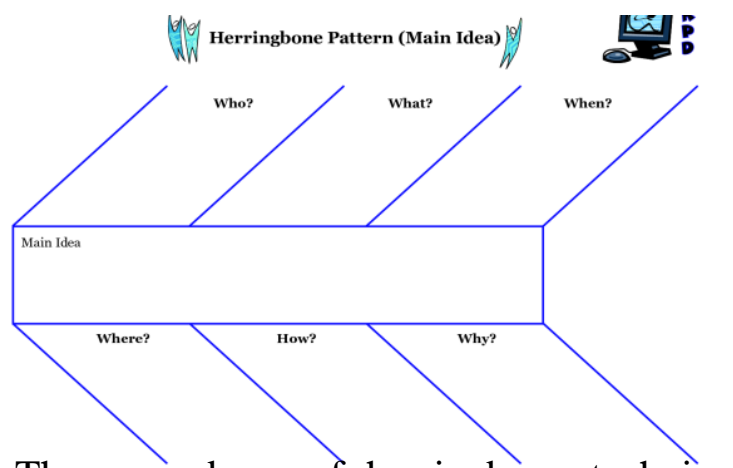

The procedures of herringbone technique are:

1) The students work in pairs. The students make a group with their friend besides them.

2) The teacher selects narrative texts. The teacher selects narrative texts which is appropriate with the reading level of the eighth grade.

3) The teacher constructs a visual diagram of the Herringbone. The teacher shows the visual diagram of Herringbone Technique to the students.

4) The teacher tells the students to record the answers to the questions on the diagram. They will look for answers to:

a) Who is the writer talking about?

b) What did they do?

c) When did they do it?

d) Where did they do it?

e) How did they do it?

f) Why did they do it?

5) The students read the text to find the answers and record the answers on the Universitas Sulawesi Barat 
diagram. The students are recording the answer of the Herringbone diagram's questions while they are reading the text.

6) The teacher shows the students how each answer fits into a slot in a main idea sentence. After the information is recorded, the students can make the main idea of the text by using the answers of $\mathrm{WH}$-questions.

7) The students write a main idea, using the information from the Herringbone diagram.

After getting the main idea by using the information from Herringbone diagram, the students write the main idea on the Herringbone diagram.

\section{Method}

In this study, the reseracher used a test as a instrumen of data collection. The test was used to measure the achievement of students in reading ability, namely post-test. The post-test was used to find out the reading achievement after the treatment.

The test used the objective test; the choice of multiple choice types was based on the following considerations: (1) It is easy and consistent; (2) It is easy to compute and determine the reliability of the test; (3) It is economical because the number of items can be answered in a short period of testing time, and it is more practical for the students to answer. They just marke the most appropriate answer in the answer sheet; each of the tests consists of multiple choices reading comprehension questions follow each reading passage. Each correct item of the answer would be given score 1 and wrong answer get score 0 . Total score was 100 . In this research, there are 30 items in the test.

In this research, the achievement test was used. The test in this research was divided into two stepsthey are pre- test and posttest.

Pre-test was given before conducting the treatment by using 90 minute (2 lesson hours), to know and check the prior knowledge or reading ability, The writer conducted a post-test after the treatments had been given. The purpose of the posttest was to know the achievement of students in reading narrative text after they are given a set of treatment.

\section{Findings and Discussion}

The researcher used pre-test and post-test in which these tests aimed at collecting data of the students' ability to reading narrative text of two groups, the experimental group and the control group. To analyze the data obtained from the test, the researcher used the t-test (test of difference) formula for independent sample.

\section{A. The Students' Ability to reading}

The data percentage of the students' score obtained through the test in experimental and control group.

Table 1. The standar's level of student's achievement in experimental group

\begin{tabular}{lllllll}
\hline \multirow{2}{*}{ No. } & \multirow{2}{*}{ Category } & \multirow{2}{*}{ Score } & \multicolumn{2}{c}{ Pre-Test } & \multicolumn{2}{c}{ Post-Test } \\
& & & Fq & \% & Fq & \% \\
\hline 1. & Excellent & $86-100$ & 0 & 0 & 30 & 100 \\
2. & Very & $71-85$ & 0 & 0 & 0 & 0
\end{tabular}

\section{EDUVELOP}

Journal of English Education and Development Universitas Sulawesi Barat 


\begin{tabular}{lllllll} 
& Good & & & & \\
3. & Good & $56-70$ & 3 & 10 & 0 & 0 \\
4. & Fairly & $41-55$ & 18 & 60 & 0 & 0 \\
& Good & & & & & \\
5. & Fair & $0-40$ & 9 & 30 & 0 & 0 \\
Total & & & 30 & 100 & 30 & 100 \\
\hline
\end{tabular}

Table above shows that before giving treatment in reading, the student's achievement were categorized fairly good classification and after giving the treatment, the achievement of the students was categorized excellent classification. It means that the students' ability in reading by using herringbone technique had improved significantly. The classification of the score of experimental group was presented in table 4.1. This table shows that before giving treatment, $3(10 \%)$ students were in good classification, 18 (60\%) students were in fairly good classification, and $9(30 \%)$ were fair. After giving treatment, $30(100 \%)$ out of 30 students were in Excellent classification.

Table 2. The standar's level of student's achievement in control group

\begin{tabular}{lllllll}
\hline & & & \multicolumn{2}{c}{ Pre-Test } & \multicolumn{2}{c}{ Post-Test } \\
No & Category & Score & F & $\%$ & Fq & $\%$ \\
& & & $\mathbf{q}$ & & & \\
\hline 1. & Excellent & $86-100$ & 0 & 0 & 29 & 96 \\
2. & Very & $71-85$ & 0 & 0 & 1 & 3,33 \\
& Good & & & & & \\
3. & Good & $56-70$ & 2 & 6,66 & 0 & 0 \\
4. & Fairl & $41-55$ & 18 & 60 & 0 & 0 \\
& Good & & & & & \\
5. & Fair & $0-40$ & 10 & 33,33 & 0 & 0 \\
\multicolumn{2}{l}{ Total } & & 30 & 100 & 30 & 100 \\
\hline
\end{tabular}

The table above, we can see that before teaching of reading text by using direc instruction, the students' achievement reading was fairly good classification. The classification of the control group was presented in table 4.2. Table shows that before teaching reading narrative text by using direc instruction $2(6,66 \%)$ student

Vol. 1 No. 2 March 2018 was in good classification, 18 (60\%) students were in fairly good classification, $10(33,33 \%)$ students were in fair classification. After teaching reading narrative text by using direc instruction where $29(96,66 \%)$ students was in Excellent classification and $1(3,333)$ students were in very good classification.

The mean score and standard deviation of the students' pre-test

Table 3. The Mean Score and Standard Deviation of the Students' Pretest.

\begin{tabular}{lll}
\hline Group & $\begin{array}{l}\text { Mean } \\
\text { score }\end{array}$ & $\begin{array}{l}\text { Standard } \\
\text { Deviation }\end{array}$ \\
\hline Experimental & 46 & 7,11 \\
Control & 45 & 6,83 \\
\hline
\end{tabular}

The mean score and the standard deviation of both groups are presented that the mean score obtained by the students in experimental group (46) was greater than the control (45); it reveals that the mean score of the pre-test obtained by the students in both are different. In order to know whether or not the mean difference of experimental and control class are statistically significant at the level of significant 0.05 , degree of freedom $\left(\mathrm{n}_{1}+\mathrm{n}_{2}\right.$ - 2) is 58, the result of calculation was shown as follows:

Table.4. The t-test of the Students' Pre-test

\begin{tabular}{lll}
\hline Variable & $\begin{array}{l}\text { t-test } \\
\text { value }\end{array}$ & $\begin{array}{l}\text { t-table } \\
\text { value }\end{array}$ \\
\hline
\end{tabular}
Universitas Sulawesi Barat 


Pre-test $\quad 0.33 \quad 2,021$

Table above shows that the t-test value (0.33) was smaller than the t-table value of the students' pre-test (2.021). Based on the result above, there was significant difference between the two mean scores.

The mean score and standard deviation of the students' post-test

Table 5. The Mean Score and Standard Deviation of the Students' Posttest

\begin{tabular}{lll}
\hline Group & $\begin{array}{l}\text { Mean } \\
\text { score }\end{array}$ & $\begin{array}{l}\text { Standard } \\
\text { Deviation }\end{array}$ \\
\hline Experimental & 97 & 2,74 \\
Control & 92 & 2,81 \\
\hline
\end{tabular}

Table 5 above that the mean score obtained the students in experimental group (97) was greater than control group (92). It appears that the mean score of the post-test obtained by the students in both group are different. In order to know whether or not the mean difference of both groups is statically significant at the level of significance 0.05 , degree of freedom $\left(n_{1}+n_{2}-2\right)$ is 58 .

The result of calculation is shown as follow:

Table 6. The t-test of the Students' Post-test

\begin{tabular}{lll}
\hline Variable & $\begin{array}{l}\text { t-test } \\
\text { value }\end{array}$ & $\begin{array}{l}\text { t-table } \\
\text { value }\end{array}$ \\
\hline Post-test & 7,24 & 2.021 \\
\hline
\end{tabular}

Table 6 shows that the t-test value $(7,24)$ is greater than the t-table value (2.021). Based on this result, it is concluded that the difference of both means is statically significant.

Vol. 1 No. 2 March 2018
Based on the description of the data collected through test showed that the student ability to read in pre-test of experimental and control group was same significantly. In experimental and control group most of the students were still classified into "fairly good" category. On the contrary in pre-test, based on the description of the data collected through test showed that the student ability to read in post-test of experimental and control group was different significantly. It was proved by the mean score rate of the students' post-test result of experimental and control group. In experimental group most of students were classified into "excellent" category while in control group most of the students were still classified into "exellent" category.

Overall, in analyzing the students' achievement in both groups based on the mean score, the researcher found that the mean score of students pre-test in experimental group (46) and control group (45) was in the same category based on scoring system by Depdiknas (2006) namely "fairly good" category while in post-test result, the experimental group (97) was in "excellent" category and the control group (92) in "excellent" category. It means that the ability of the students both groups were different after given treatments in which the students' ability of the experimental group was greater than the students' ability of the control group.

Based on the explanation above the researcher concludes that the t-test value $(7,24)$ is greater than t-table value $(2.000) \alpha$ Universitas Sulawesi Barat 
$=0.05$, see Table 4.6. It means that $\mathrm{H}_{1}$ was accepted and $\mathrm{H}_{0}$ was rejected. It is concluded that there was a significant difference before treatment in pre-test and after treatment in post-test. In other words, there was an improvement on the students' reading ability between post-test in both experimental and control group after the treatment. Finally, the researcher states that the use of heerringbone technique is better in improving the students' reading ability than the conventional technique.

\section{Conclusion}

From the analysis and the discussion in the previous chapters, the writer draws some conclusions, as the result of the study in reading narrative text using Herringbone Technique of the eighth grade students of SMP Negeri 9 Parepare in the academic year of 2013/2014. In this chapter, the writer presents the conclusions and suggestions to the reader, especially for the students and teachers.

a. The result of data analysis showed that there were $3(10 \%)$ students were in good classification, 18 (60\%) students were in fairly good, and $9(30 \%)$ were fair .After giving treatment, $30(100 \%)$ out of 30 students were in excellent classification. In addition, the data showed that the means of students' proficiency in reading narrative text of the experimental group was 7,11 and the mean of the students' proficiency of the control group was 6,83. Based on the data above, the writer concluded that teaching reading narrative text by using Herringbone Technique to the eighth grade students of SMP Negeri 9 Parepare in the academic year of 2013/2014 was better than teaching reading narrative text by using Direct Instruction. In addition, Herringbone Technique which was applied in reading narrative text could be an effective technique in teaching reading narrative text.

b. The result of data analysis showed that there were $2(6,66 \%)$ student was in good classification, 18 (60\%) students were in fairly good classification, 10 $(33,33 \%)$ students were in fair classification. After teaching reading narrative text by using direc instruction where $29(96,66 \%)$ students was in Excellent classification and $1(3,333)$ students were in very good classification. In addition, the data showed that the means of students' proficiency in reading narrative text of the control group was 97 and the means of students' proficiency of the experimental group was 92. Based on the data above, the writer concluded that teaching reading narrative text by using Direct Instruction was worse than teaching reading narrative text by using Herringbone technique to the eighth grade students of SMP Negeri 9 Parepare in the academic year of 2013/2014.

c. After applying the $t$-test formula, it was known that $t$-test measurement was obtained 7,24 (tvalue). Meanwhile, from the table of significance $5 \%$ with df $(30+30-2=58)$, it was shown by Universitas Sulawesi Barat 
the result of t-table was 2,021. It means that tvalue was higher than ttable, so there was significant difference in the achievement of students between those who were taught by using Herringbone Technique and by using Direct Instruction in reading narrative text to the eighth grade students of SMP Negeri 9 Parepare in the academic year of 2013/2014. It can be concluded that Herringbone Technique provides an effective study when it was applied to reading material. It means that teaching reading narrative by using Herringbone Technique is more effective than teaching reading narrative text by using Direct Instruction to the eighth grade students of SMP Negeri 9 Parepare in the academic year of 2013/2014.

\section{References}

Alan, et al. (2005). The teaching knowledge test course. Cambridge: UniversityPress.

Anggreani. 2012. The Effect Of Herringbone Strategy Toward Students' Reading Ability Of Narrative Text Of Eighth Grader At Smpn 17 Kota Jambi. Unpublised Skripsi. Jambi: IKIP PGRI Jambi

Asriadi. 2011. The Use Of Directed Reading Thinking Activity To Increase Students' Reading Comprehention. Unpublised Thesis. Parepare: English Language Education Department UMPAR

Balajthy, Ernest and Sally Lipa-Wade. 2003. Struggling Readers: Assessment and Instruction in

Vol. 1 No. 2 March 2018
Grades K-6. New York: Guilford Press.

Canady, Robert Lynn and Michael D. Rettig. 1996. Teaching in the Block: Strategies for Engaging Active Learners. Princeton: Eye on Education.

Deegan,J. Herringbone Technique. Online at http: //www.teacherweb. com /PA /Nazareth Area Middle School/ The Specialist Team/ Herringbone Technique.doc [accessed 14/03/13]

Edgar, Christopher and Gary Lenhart. 2001. The Teachers and Writers Guide to Classic American Literature. New York: Teachers \& Writers Collaborative.

Gallant, Janet A. 2008. New York State Grade 3 Elementary-Level English Language Arts Test. New York: Barrons Educational Series Inc.

Gay, L. R. 1981. Education Research Competencies for Analysis and Application.Second Edition.Colombus Ohio. Charles E. Meril Publishing.

Harmer, Jeremy. 1998. How to Teach English. Harlow: Addison Wesley Longman Limited.

Hasnah. 2013. The Effectiveness Of Team Games Tournament (TGT) In Improving Students Vocabulary By Using Visual AIDS (A Case Study At Modaputa English Course ). Unpublished Thesis. Parepare: Universitas Sulawesi Barat 
English Language Education Department UMPAR

Isdaryanto.

2014.

http://www.isdaryanto.com/definitio n-of-narrative-text, accesed on 1 Mei 2014)

Keir, June. 2009. Imaginative Narruıves. Perfecting the Art of Writing Stories. Greenwood: Ready-Ed Publications.

Killen, Roy. 2006. Effective Teaching Strategies: Lessons from Research and Practice. South Melbourne: Thomson Learning Australia.

Kothari, C. R. 2004. Research Methodology: Methods \& Techniques (Second Revised Edition). New Delhi: New Age International (P) Ltd.

McKnight, Katherine S. 2010. The Teacher's Big Book of Graphic Organizers: 100 Reproducible Organizers that Help Kids with Reading, Writing, and the Content Areas. San Francisco: Jossey-Bass.

Mikulecky, Beatrice S. and Linda Jeffries. 1996. More Reading Power. New York: Addison-Wesley.

Morgado Nelly Fernandez. (2009). Students' Performance and Perception. Journal Of The Reading Matrix, vol. 9 no. 1, April 2009.

Nunan, D. (1988). Research methods in language learning. Cambridge: CUP.

Vol. 1 No. 2 March 2018
Rafain, Desima. 2013. The Effect Of Herringbone Technique On Students' Reading Comprehension In Recount Text At Second Grade Of SMPN 2 Enam Lingkung Padang Pariaman, Journal Of English Teacing, vol. 2 no. 1, September 2013, Serie A

Rodman, Marsha L. 2007. A Study of Intensive, Systematic Direct Instruction for an Austic Child. Capella University: ProQuest.

Romero, Angelita D. and Rene C. Romero. 1985. Developmental Reading: A Skill Text for College Students. Manila: Rex Book Store.

Ruffin, Tiece M. (2009). Adaptations to Meet the Needs of Secondary English Language Learners with Learning Disabilities. Journal Of The Reading Matrix, vol. 9 no. 1, April 2009.

Schug, Mark C., Sara G. Tarver, and Richard D. Western. 2001. Direct Instruction and The Teaching of Early Reading. Wisconsin's Teacher-Led Insurgency. Pp. 3.

Saputra, Benni, 2012. The Effect Of Herringbone Technique Toward Students' Reading Comprehension For Tenth Grade At SMK Negeri 1 Lubuk Sikaping. Unpublished Thesis. Lubuk Sikaping: STKIP PGRI Sumatera Barat.

Spierling, Ulrike and Nicolas Szilas (eds). 2008. Interactive Storytelling: First Joint International Conference on Interactive Digital Storytelling, ICIDS 2008, Erfurt, Germany, Universitas Sulawesi Barat 
November 26-29, 2008,

Proceedings. Berlin: Springer.

Sugiarti, Nina. 2008. Improving Reading Comprehension Abylity of The First Years Student Of SMKN 2 Parepare Through Sntences Strips. Unpublished Thesis. Parepare: English Language Education Department UMPAR

Thaler, Engelbert. 2008. Teaching English Literature. Paderborn: Verlag Ferdinand Schöningh $\mathrm{GmbH} \& \mathrm{Co}$. KG.

Advantages and Disadvantages of Graphic Organizer. Online at http:/ /www.ehow.com/ facts_ 5522538_ advantages- disadvantages-graphicorganizer.html [accessed 13/04/13]

Learning Strategies Database. Online at http:// www.muskingum.edu/ cal /database /general /organization.html [accessed 14/03/13]

Teaching Methods Direct Instruction. Online at http:// www.usask.ca /education /coursework /mcvittiej /methods /direct.h tml 